\title{
Substrate selection of the caprellid Caprella dilatata (Crustacea, Amphipoda)
}

\author{
Selección de sustrato del caprélido Caprella dilatata \\ (Crustacea, Amphipoda)
}

\section{Mariana B. Lacerda ${ }^{1}$ and Setuko Masunari ${ }^{1}$}

${ }^{1}$ Programa de Pós-Graduação em Zoologia, Departamento de Zoologia, Universidade Federal do Paraná, Centro Politécnico, Bairro Jardim das Américas, Caixa Postal 19020, CEP 81531-980 Curitiba, PR, Brasil. lacerdamariana@yahoo.com.br

Resumen. - La diversidad del espacio y la variabilidad de las condiciones ambientales que afectan la calidad del hábitat para los organismos son factores determinantes en la selección de un hábitat ideal. El presente estudio tuvo como objetivo determinar la selección del sustrato del anfípodo caprélido Caprella dilatata, en ambientes naturales al largo de la costa del sur de Brasil y en condiciones de laboratorio. Se contabilizaron 31 sustratos biológicos distintos que albergaban a invertebrados, la mayoría fueron sustratos algales. C. dilatata fue registrada en once de estos sustratos, y resultó ser especie dominante únicamente en algas finamente ramificadas, ascidias, briozoos y en las superficies de las boyas y cuerdas. Los experimentos de laboratorio para selección de sustrato por C. dilatata se realizaron utilizando dos y cuatro especies de algas que tenían contrastante ramificación; Gracilaria cervicornis, Pterocladia capillacea, Sargassum cymosum y Ulva fasciata. En el primer experimento, caprélidos fueron trasladados a tres acuarios que contenían combinaciones variadas de dos sustratos de algas con un total de nueve combinaciones. Para el segundo experimento (cuatro algas), todas las especies de algas se combinaron en cada acuario. Los anfípodos obtenidos para experimentos en laboratorio mostraron el color del dermatoesqueleto siempre muy similar al color de las algas. Hubo una fuerte preferencia de caprélidos por el sustrato original. A pesar de la morfología cosmopolita de C. dilatata para la selección del sustrato, los individuos se encuentraron principalmente en sustratos estructuralmente complejos, y demostraron la importancia del camuflaje en estos caprélidos.

Palabras clave: Caprellidae, algas, sustratos artificiales, condiciones de laboratorio

\begin{abstract}
The diversity of space and the variability of environmental conditions that affect habitat quality for organisms, are determining factors in the selection of an ideal habitat. The present study aimed to understand the substrate selectivity of a caprellid amphipod, Caprella dilatata, in natural environments along the southern Brazilian coast and in laboratory conditions. A total of 31 biological substrates sheltering invertebrates were collected across various localities. C. dilatata was recorded in 11 substrate samples, and was a dominant species only in finely branched and softly surfaced algal substrate, ascidian and bryozoan colonies, and the surfaces of buoys and ropes. Laboratory experiments for substrate selection by C. dilatata were performed under two conditions: two-algal substrates and four-algal substrates. The phytals of Gracilaria cervicornis, Pterocladia capillacea, Sargassum cymosum and Ulva fasciata were selected for the experiments due to their contrasting degrees of ramification. In the first experiment (two-algal substrates), caprellids were transferred to three aquaria containing varied combinations of two algal substrates with a total of nine combinations. For the second experiment (four-algal substrates), all species of algae were combined together in each aquarium. Amphipods obtained for laboratory experiments always showed an exoskeleton color very close to that of the original algal substrate. Caprellids showed a strong preference for the original algal substrate. Despite the cosmopolitan morphology of $\mathrm{C}$. dilatata for selection of the substrate, the individuals were mostly found in structurally complex substrates, and the experiments show the importance of camouflage for these caprellids.
\end{abstract}

Key words: Caprellidae, phytals, artificial substrates, laboratory conditions 


\section{INTRODUCTION}

The selection of an ideal habitat is a complex process for organisms due to the diversity of space and the variability of environmental conditions that affect habitat quality, including amount and quality of food resources, predation and competition pressures, and local climate conditions (Gustafsson 1987, Robinson et al. 1995, Sinervo \& Denardo 1996, Martin 2001, Shima \& Osenberg 2003). Morris (2003) defines this selection as the preference for a non-random group of available habitats used by individuals. Rosenzweig (1981) considers this to be one of the main relationships allowing for the coexistence of species.

Evaluation of the effects of habitat modification on an individual can be applied to the population level as the knowledge of patterns and intensities of resource selection by individuals in heterogeneous environments is fundamental to understanding animal selective behavior (Rosenberg \& Mckelvey 1999). Biotopes with varied degrees of differentiation have been compared in populations of birds and other terrestrial vertebrates (Borges \& Araújo 1998, Barbosa et al. 2008); however, the utilization of abundant and small invertebrate animals living in intertidal areas is usually more viable because they primarily live in easily accessible biotopes, making it possible to take larger and more significant samples for laboratory experiments (Fenchel 1975, Fenchel \& Kofoed 1976).

Caprellid amphipods are usually found in biological substrates as dwellers on algae, sponges, hydroids, and bryozoans. Some species show close dependence to certain substrates that provide several benefits such as safety against predators and water movement (Keith 1971). While some caprellid species do not seem to prefer a specific substrate, colonizing a great variety of substrates (Guerra-García 2001, Thiel et al. 2003), other species are exclusively associated with a certain substrate or group of substrates and exhibit morphological adaptations to their habitat (McCain 1968, Caine 1978). For example, Takeuchi \& Hirano (1995) observed that caprellid species inhabiting algae with elongate or filamentous thallii have characteristics in common; the resting position of the body with the long axes nearly parallel to the substrate, the basis of gnathopod 2 is shorter than half the length of pereonite 2 and the gills are basally bent forward. Another adaptational feature of some caprellids is the capacity to change the exoskeleton color according to the substrate they are sheltering in. Experiments conducted with Caprella californica by Keith (1971) proved that this caprellid slightly changed its body color closer to the substrate color in about five hours, although the adaptation does not appear to be complete until after ecdysis.

Additional research has shown that the composition and density of caprellids are influenced by structural elements of the algal substrate (phytal), such as ramification degree and thallii consistence (Masunari 1982, Dutra 1988, Dubiaski-Silva \& Masunari 1995, Leite \& Turra 2003, Leite et al. 2007). These features regarding microhabitat occupation between caprellids species may increase interspecific competition (Aoki 1999). In this context, Shucksmith et al. (2009) showed that invasive species can displace native species with similar habits when the resource space is limited.

Caprella dilatata Krøyer, 1843 is a caprellid amphipod characterized by a robust body bearing well-developed lateral projections in the pereonites 3 and 4 . This species is distributed throughout the Atlantic Ocean and along the Mediterranean coast (Masunari \& Takeuchi 2006). In Brazil, this species was recorded from the phytal of Sargassum cymosum C. Agardh (Jacobucci et al. 2002) and it was associated with biological substrates such as bivalve shells, bryozoans, sponges or on the surfaces of ropes and buoys in mussel-farming operations (Masunari \& Takeuchi 2006). The present study aims to understand the substrate selectivity of the caprellid $C$. dilatata in the laboratory and in natural environments along the coast of the Brazilian states of Paraná and Santa Catarina.

\section{MATERIALS AND METHODS}

\section{SUBSTRATE SELECTION IN NATURE}

Caprellids were obtained from samples of biological and artificial substrates (Table 1) collected from coastal areas of the Brazilian states Paraná and Santa Catarina (25-28 ${ }^{\circ}$; $\left.48-49^{\circ} \mathrm{W}\right)$. Most samples were deposited at the Laboratory for Ecology of Crustacea, Laboratory for Cnidaria Studies, Laboratory for Ecology and Systematics of Ascidiacea, and Laboratory for Benthos, all belonging to the Federal University of Paraná and the Museum of Natural History of Capão da Imbuia. In sublittoral localities, samples were obtained with autonomous dives at depths that varied from 1.5 to $11.0 \mathrm{~m}$. All biological substrates were scraped from the rocky surface with a metallic spatula, wrapped in plastic bags, and transported to the laboratory in an icebox for subsequent preservation in $70 \%$ alcohol.

The samples were sorted under a stereoscope, and the 
caprellids were separated and identified following specialized bibliography: McCain (1968), Krapp-Schickel (1993), Serejo (1998), Masunari \& Takeuchi (2006). Then, Caprellid abundance in the different substrates (biological or artificial) was calculated as the relative frequency of $C$. dilatata in relation to total caprellids from each substrate due to the diversified size of the samples.

\section{EXPERIMENTS ON SUBSTRATE SELECTION}

The phytals of Gracilaria cervicornis (Turner) J. Agardh, Pterocladia capillacea (Gmelin) Bornet \& Thuret, Sargassum cymosum C. Agardh, and Ulva fasciata Delile were chosen due to the contrasting ramification degrees of these algal substrates. Gracilaria, Pterocladia and Sargassum were branched algae and they had threedimensional growth, whereas Ulva looked like a long ribbon with a two-dimensional form.

Additionally, the first three phytals are known to shelter dense populations of Caprella dilatata, whereas Ulva does not. Samples of these phytals were collected from the rocky shore of Caiobá Beach, Matinhos, state of Paraná, in August and September 2009. They were wrapped in a plastic bag, their holdfasts were scraped from the rocky surface, and they were packed with a small amount of seawater and transported to the laboratory in an icebox.

In the laboratory, the four-algal substrates with associated fauna, including caprellids, were maintained separately in aquaria filled with seawater brought from the collection site for acclimatization. This was performed at room temperature (about $21^{\circ} \mathrm{C}$ ) during a 24-hour period. Subsequently, all animals were extracted with tweezers from the algal substrates, and caprellids were transferred to another aquarium containing seawater and a few thallii of the algal substrate in which they were originally found. The remaining associated fauna was discarded to avoid the eventual interference of other factors such as predation and competition during experimentation. The algal substrates, free of associated fauna, were kept separately according to species in maintenance aquaria.

The individuals of $C$. dilatata selected for the experiments were composed exclusively of adults without sexual discrimination. Juveniles were excluded because they are difficult to observe without the aid of optical equipment. Food was only available in the maintenance tanks and it was not offered during the experiments.

The architecture of each algal substrate was characterized by taking measurements of the following morphometrical parameters: the width of the main and secondary axes and, whenever possible, the distance among the ramifications. For each algal substrate, 30 measures of each parameter were taken, and mean values were calculated and compared through analysis of variance (ANOVA) with a Tukey post hoc test.

EXPERIMENTS IN AQUARIA CONTAINING TWO SPECIES OF ALGAL SUBSTRATE

Three sets of three glass aquaria $(20 \times 20 \times 20 \mathrm{~cm})$, totaling nine combinations, of two-algal substrates were used. In each set (i.e., each treatment), caprellids from a phytal (e.g., Gracilaria) were transferred to three aquaria containing varied combinations of two algal substrates (see Table 1 for remaining combinations). They were picked up with a delicate brush and released at the water surface in the halfway point from aquarium walls. All algal substrates free of associated fauna had the same biomass (humid weight $=7 \mathrm{~g}$ ). They were previously anchored in a perforated plastic plate, and each pair of algae was placed in the aquarium on opposite sides. The water of the aquaria was aerated with a weak pump aerator.

The number of released caprellids per aquarium depended on their availability: 15 individuals from Gracilaria and Sargassum (treatments 1 and 3) and 20 individuals from Pterocladia (treatment 2). No caprellid was reused in the experiments.

Table 1. Experimental drawing of the combinations of algal substrate in three treatments with 5 replicates each / Diseño experimental de las combinaciones de sustrato de algas en tres tratamientos con 5 repeticiones cada uno

\begin{tabular}{lccc}
\hline \multirow{2}{*}{$\begin{array}{l}\text { Treatment } \\
\text { Pair of algal substrates }\end{array}$} & Gracilaria phytal & Pterocladia phytal & Sargassum phytal \\
\cline { 2 - 4 } & Gracilaria + Pterocladia & Pterocladia + Gracilaria & Sargassum + Gracilaria \\
Aquarium 1 & Gracilaria + Sargassum & Pterocladia + Sargassum & Sargassum + Pterocladia \\
Aquarium 2 & Gracilaria + Ulva & Pterocladia + Ulva & Sargassum + Ulva \\
Aquarium 3 & & & \\
\hline
\end{tabular}


Table 2. Total abundance and relative frequency, of Caprella dilatata samples analyzed in several substrates occurring in two intertidal zones / Abundancia total, frecuencia relativa y muestras analizadas de Caprella dilatata en diferentes sustratos que ocurren en dos zonas intermareales

\begin{tabular}{|c|c|c|c|c|}
\hline Substrates & $\begin{array}{l}\text { Intertidal } \\
\text { zones }\end{array}$ & $\begin{array}{l}\text { Number of } \\
\text { samples }\end{array}$ & $\begin{array}{c}\text { Total } \\
\text { abundance }\end{array}$ & $\begin{array}{c}\text { Relative } \\
\text { frequency (\%) }\end{array}$ \\
\hline \multicolumn{5}{|l|}{ PHYTALS } \\
\hline Agardhiella sp. & midlittoral & 3 & 0 & 0 \\
\hline Amphiroa beauvoisii & midlittoral & 5 & 0 & 0 \\
\hline Bryothamnion sp. & midlittoral & 3 & 0 & 0 \\
\hline Chnoospora sp. & midlittoral & 1 & 0 & 0 \\
\hline Cryptonemia sp. & midlittoral & 1 & 0 & 0 \\
\hline Gelidium sp. & midlittoral & 1 & 0 & 0 \\
\hline Gigartina sp. & midlittoral & 2 & 0 & 0 \\
\hline Gracilaria sp. & midlittoral & 4 & 0 & 0 \\
\hline Gracilaria verrucosa & midlittoral & 3 & 49 & 31.6 \\
\hline Gymnogongrus sp. & midlittoral & 5 & 0 & 0 \\
\hline Hypnea sp. & midlittoral & 2 & 0 & 0 \\
\hline Laurencia sp. & midlittoral & 1 & 0 & 0 \\
\hline Padina sp. & sublittoral & 1 & 0 & 0 \\
\hline Polysiphonia sp. & midlittoral & 1 & 0 & 0 \\
\hline Pterocladia capillacea & midlittoral & 9 & 632 & 82.3 \\
\hline Pterosiphonia sp. & midlittoral & 6 & 2265 & 97.9 \\
\hline Sargassum spp. & sublittoral & 14 & 56 & 26.2 \\
\hline Spyridia aculeata & sublittoral & 2 & 0 & 0 \\
\hline Ulva fasciata & midlittoral & 4 & 0 & 0 \\
\hline \multicolumn{5}{|l|}{ ANIMAL COLONIES } \\
\hline \multicolumn{5}{|l|}{ ANNELIDA } \\
\hline Phragmatopoma sp. & midlittoral & 2 & 0 & 0 \\
\hline Colony of Polychaeta & sublittoral & 1 & 0 & 0 \\
\hline \multicolumn{5}{|l|}{ ASCIDIACEA } \\
\hline Didemnum perlucidum & - & 1 & 48 & 87.3 \\
\hline Styela plicata & - & 1 & 94 & 100 \\
\hline \multicolumn{5}{|l|}{ BRYOZOA } \\
\hline Bugula neritina & sublittoral & 2 & 1119 & 83.1 \\
\hline \multicolumn{5}{|l|}{ CIRRIPEDIA } \\
\hline Barnacles & midlittoral & 2 & 0 & 0 \\
\hline \multicolumn{5}{|l|}{ HYDROZOA } \\
\hline Hydrozoa spl & midlittoral & 3 & 0 & 0 \\
\hline Dynamena crisioides & midlittoral & 2 & 0 & 0 \\
\hline Macrorhynchia philippina & midlittoral & 1 & 2 & 0.8 \\
\hline Sertularia marginata & sublittoral & 2 & 0 & 0 \\
\hline \multicolumn{5}{|l|}{ OYSTER FARMING } \\
\hline Buoys and Ropes & - & 1 & 0 & 0 \\
\hline Oyster shells & - & 3 & 1 & 0.1 \\
\hline \multicolumn{5}{|l|}{ MUSSEL FARMING } \\
\hline Buoys & - & 1 & 1211 & 90 \\
\hline Ropes & - & 2 & 324 & 70.1 \\
\hline SEDIMENT & - & 5 & 0 & 0 \\
\hline $\begin{array}{l}\text { EXPERIMENTAL METALLIC } \\
\text { PLATES }\end{array}$ & - & 4 & 0 & 0 \\
\hline
\end{tabular}


The observations were performed over a $24 \mathrm{~h}$ period, during which caprellids that were sheltering among thallii of the algal substrate were counted at intervals of $6 \mathrm{~h}, 12$ $\mathrm{h}$ and $24 \mathrm{~h}$. Five replicates were carried out for each aquarium for a total of 45 counts. During these counts, a glass plate was inserted into the middle of the aquarium to separate the areas corresponding to each algal substrate, avoiding eventual count errors caused by water movement or the displacement of caprellids from one area to another. After the end of each experiment for each replicate, the algal substrate was returned to the maintenance aquarium, the experimental aquaria were cleaned, and the water was discarded.

ANOVA was applied to detect significant differences in the numbers of caprellids that had selected the algal substrate with a Tukey post hoc test, using a significance level of 0.05 .

\section{EXPERIMENTS IN AQUARIA CONTAINING FOUR SPECIES OF ALGAL SUBSTRATES}

Aquaria of the same size from previous experiments were used, in which the four-algal substrates (Gracilaria, Pterocladia, Sargassum and Ulva) were placed simultaneously, one in each corner. These algae, free from associated fauna, weighed $7 \mathrm{~g}$ and were previously anchored to a perforated plastic plate. The water of the aquarium was aerated with a weak pump aerator. Twenty caprellids coming from Pterocladia phytal and ten from Sargassum phytal were utilized in this experiment, and five replicates were performed for each treatment. No caprellids coming from Gracilaria phytal were used because this alga produced an exudation that killed most of them. During the counting of caprellids, the algal substrate was carefully separated to avoid interference caused by water movement or the displacement of caprellids from one substrate to another. All results were represented as percentage in order to compensate the diverse number of caprellids utilized in the experiments.

\section{Results}

\section{SUBSTRATE SELECTION IN NATURE}

A total of 34 substrates were analyzed, of which 31 were biological (19 phytals, ten animal colonies, the shell surface of bivalve and a sessile community over a metallic plate), two were artificial (ropes and buoys in marine farms) and one was non-consolidate (sediment)

Caprella dilatata was recorded in 11 substrates of diversified origin. It was a dominant species on the phytals of Pterosiphonia (97.9\% of the total caprellids epifauna), Pterocladia capillacea (82.3\%) and, on colonies of the ascidians Styela plicata (100\%) and Didemnum perlucidum (87.3\%), a branched colony of the bryozoan Bugula neritina (83.1\%), and buoys (90.0\%) and ropes (70.1\%) utilized in mussel-farming operations (Table 2).

\section{EXPERIMENTS ON SUBSTRATE SELECTION}

Caprellids obtained from phytals showed different sizes and an exoskeleton color closely resembling the algal substrate over which they were living. The individuals found on Pterocladia had a garnet color (redish), those on Sargassum were brown, and those on Gracilaria were a brown color (dark yellow). Furthermore, caprellids coming from Sargassum were larger and more robust than the others.

Each algal substrate showed characteristic morphometric measurements (Table 3); however, the

Table 3. Average and standard deviation of the diameter of the main and secondary axes and the distances of branches of four alga species used as substrates. Different letters ( $a, b$ and $c$ ) indicate significant differences within alga measurements among species (Tukey's post hoc test, $\mathbf{P}<\mathbf{0 . 0 5}$ ) / Media y desviación estándar del diámetro de los ej es principales y secundarios y la distancia entre las frondas de cuatro especies de algas usadas como sustrato. Letras distintas ( $\mathrm{a}, \mathrm{b}$ y $\mathrm{c}$ ) indican diferencias significativas en las mediciones de algas entre las especies (Tukey post hoc, $\mathrm{P}<0,05$ )

\begin{tabular}{lcccc}
\hline & \multicolumn{4}{c}{ Alga-substrate } \\
Measurements (mm) & $\begin{array}{c}\text { Gracilaria } \\
\text { cervicornis }\end{array}$ & $\begin{array}{c}\text { Pterocladia } \\
\text { capillacea }\end{array}$ & $\begin{array}{c}\text { Sargassum } \\
\text { cymosum }\end{array}$ & $\begin{array}{c}\text { Ulva } \\
\text { fasciata }\end{array}$ \\
\hline Diameter main axes & $1.49 \pm 0.39 \mathrm{a}$ & $1.14 \pm 0.26 \mathrm{a}$ & $1.10 \pm 0.20 \mathrm{a}$ & $9.42 \pm 3.15 \mathrm{~b}$ \\
Diameter secondary axes & $1.08 \pm 0.36 \mathrm{a}$ & $0.43 \pm 0.23 \mathrm{~b}$ & $3.46 \pm 1.43 \mathrm{c}$ & - \\
Distance of the ramifications & $2.74 \pm 1.19 \mathrm{a}$ & $0.76 \pm 0.48 \mathrm{~b}$ & $3.49 \pm 1.04 \mathrm{c}$ & - \\
\hline
\end{tabular}


average diameter of the main axes did not differ significantly among branched algal substrates (range of variation from 1.10 to $1.49 \mathrm{~mm}$ ). Only Ulva differed from the others $\left(\mathrm{F}_{(3,116)}=197.6 ; P<0.001\right)$ by presenting a flat axis with a $9.42 \mathrm{~mm}$ average width. On the other hand, the secondary axes differed significantly among branched algae, with Sargassum possessing the largest diameter (3.46 mm), followed by Gracilaria $(1.08 \mathrm{~mm})$, and Pterocladia $(0.43 \mathrm{~mm})\left(\mathrm{F}_{(2,87)}=102.0 ; P<0.001\right)$. Furthermore, Pterocladia exhibited the highest degree of ramification due to its small distance between branches $(0.76 \mathrm{~mm}, P<0.05)$, followed by Gracilaria $(2.74 \mathrm{~mm})$ and Sargassum (3.49 mm) (Table 3).

\section{EXPERIMENTS IN AQUARIA CONTAINING TWO SPECIES OF} ALGAL SUBSTRATES

The preference of caprellids for their respective original algal substrate was always statistically significant (Table 4, Figs. 1-3). In the Gracilaria treatment (aquaria with released caprellids coming from Gracilaria phytal), averages from $6.6 \pm 2.0$ to $11.8 \pm 0.8$ caprellids were recorded sheltering in Gracilaria, $1.6 \pm 0.5$ to $3.0 \pm 0.7$ in Pterocladia, $3.0 \pm 2.5$ to $4.6 \pm 1.5$ in Sargassum and $1.2 \pm$ 0.8 to $2.4 \pm 1.8$ in Ulva (from a total of 15 initial caprellids) (Fig. 1). In the Pterocladia treatment, from $11.6 \pm 3.1$ to $14.8 \pm 4.5$ caprellids chose Pterocladia, $3.6 \pm 4.4$ to $5.0 \pm$ 4.7 Gracilaria, $4.0 \pm 1.0$ to $4.8 \pm 2.2$ Sargassum and $3.0 \pm$ 2.0 to $4.4 \pm 1.1$ Ulva (from a total of 20 initial caprellids) (Fig. 2). In the Sargassum treatment, from $6.6 \pm 2.7$ to 8.2 \pm 3.5 caprellids preferred Sargassum, $4.6 \pm 2.3$ to $6.4 \pm 2.3$ Gracilaria, $4.8 \pm 1.5$ to $6.2 \pm 1.3$ Pterocladia and $3.6 \pm 1.5$ to $5.0 \pm 2.3$ Ulva (from a total of 15 initial caprellids) (Fig. $3)$. The absolute total number of deaths that occurred during 24 hour-experiments varied from 1 to 11 in Gracilaria treatment and from 1 to 5 in Pterocladia and Sargassum treatments. Dead animals were always found on the bottom or in the wall of the aquarium, out of the vegetated area.

Table 4. ANOVA results that compare the numbers of caprellids that had selected the algal substrate in experiments. Algae combination per aquarium as shown in Table 1 / Resultados de ANOVA aplicado para detectar diferencias significativas en el número de caprélidos que habían seleccionado el sustrato en los experimentos, según combinaciones de pares de algas por acuario mostrados en Tabla 1

\begin{tabular}{lrrr}
\hline & df & F & $P$ \\
\hline Aquaria containing two species of algal substrates & & & \\
$\quad$ Gracilaria treatment & & & \\
$\quad$ Aquarium 1 & 3 & 47.0 & $<0.0001$ \\
Aquarium 2 & 3 & 27.7 & $<0.0001$ \\
Aquarium 3 & 3 & 125.6 & $<0.0001$ \\
Pterocladia treatment & & & \\
Aquarium 1 & 3 & 70.3 & $<0.0001$ \\
Aquarium 2 & 3 & 143.3 & $<0.0001$ \\
Aquarium 3 & 3 & 210.8 & $<0.0001$ \\
Sargassum treatment & & & $<0.0001$ \\
Aquarium 1 & 3 & 38.2 & $<0.0001$ \\
Aquarium 2 & 3 & 104.4 & $<0.0001$ \\
Aquarium 3 & 3 & 34.0 & \\
Aquaria containing four species of algal substrates & & & $<0.0001$ \\
Pterocladia treatment & 5 & 32.0 & \\
Sargassum treatment & 5 & 16.1 & $<0.0001$ \\
\hline
\end{tabular}




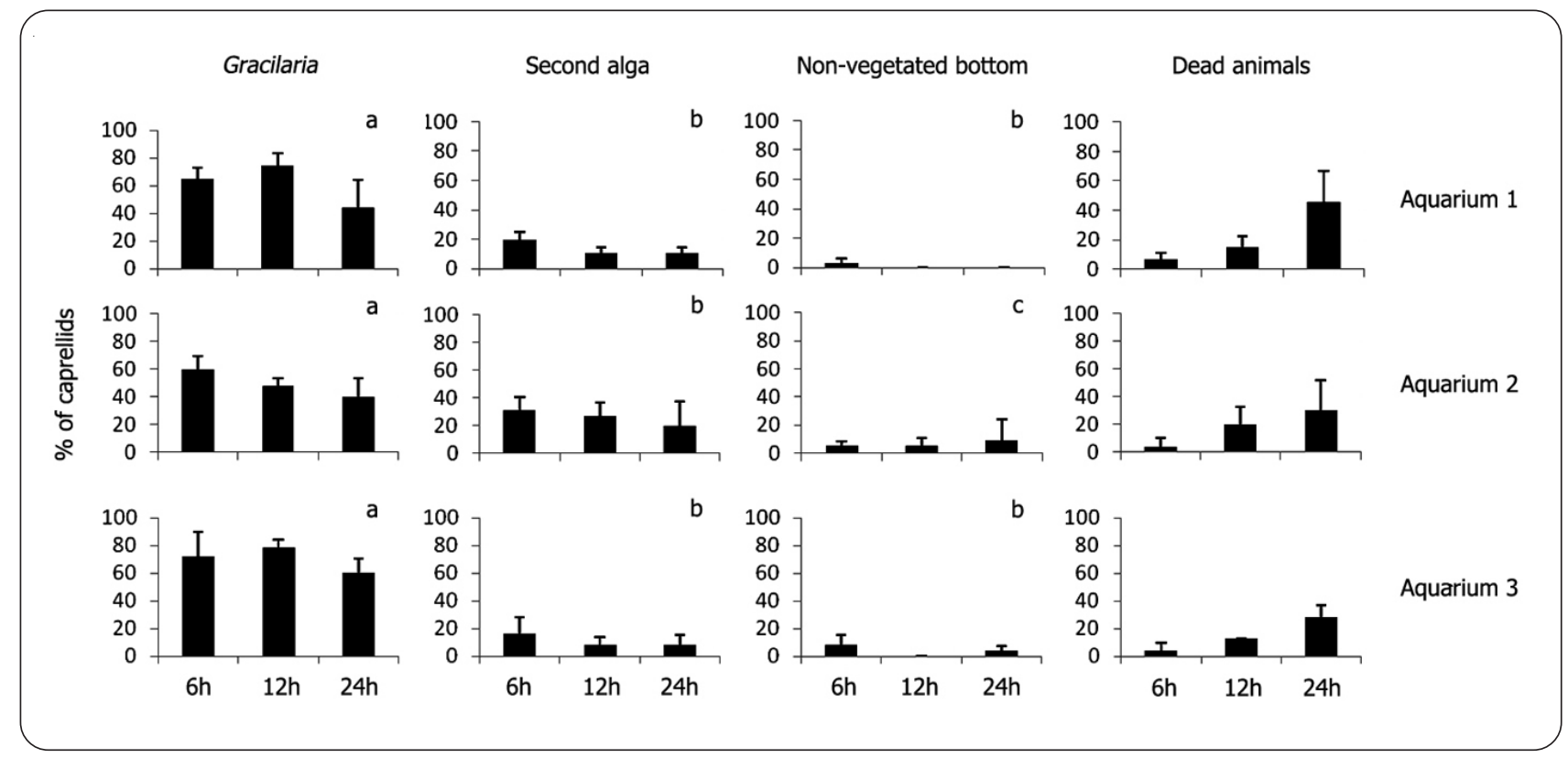

Figure 1. Gracilaria treatment (initial $n=15)$. Percentage average of caprellids found in the three counts $(6,12$ and $24 \mathrm{~h})$ in each algal substrate. Algae combination per aquarium as shown in Table 1. Different letters indicate significant differences (Tukey's post hoc tests, $\mathbf{P}<\mathbf{0 . 0 5}$ ) / Tratamiento de Gracilaria ( $\mathrm{n}$ inicial $=15$ ). Porcentaje medio de caprélidos en tres observaciones $(6,12$ y $24 \mathrm{~h}$ ) en cada sustrato de algas, según combinaciones de pares de algas por acuario mostrados en Tabla 1. Letras distintas indican diferencias significativas (Tukey post hoc, $\mathrm{P}<0,05)$

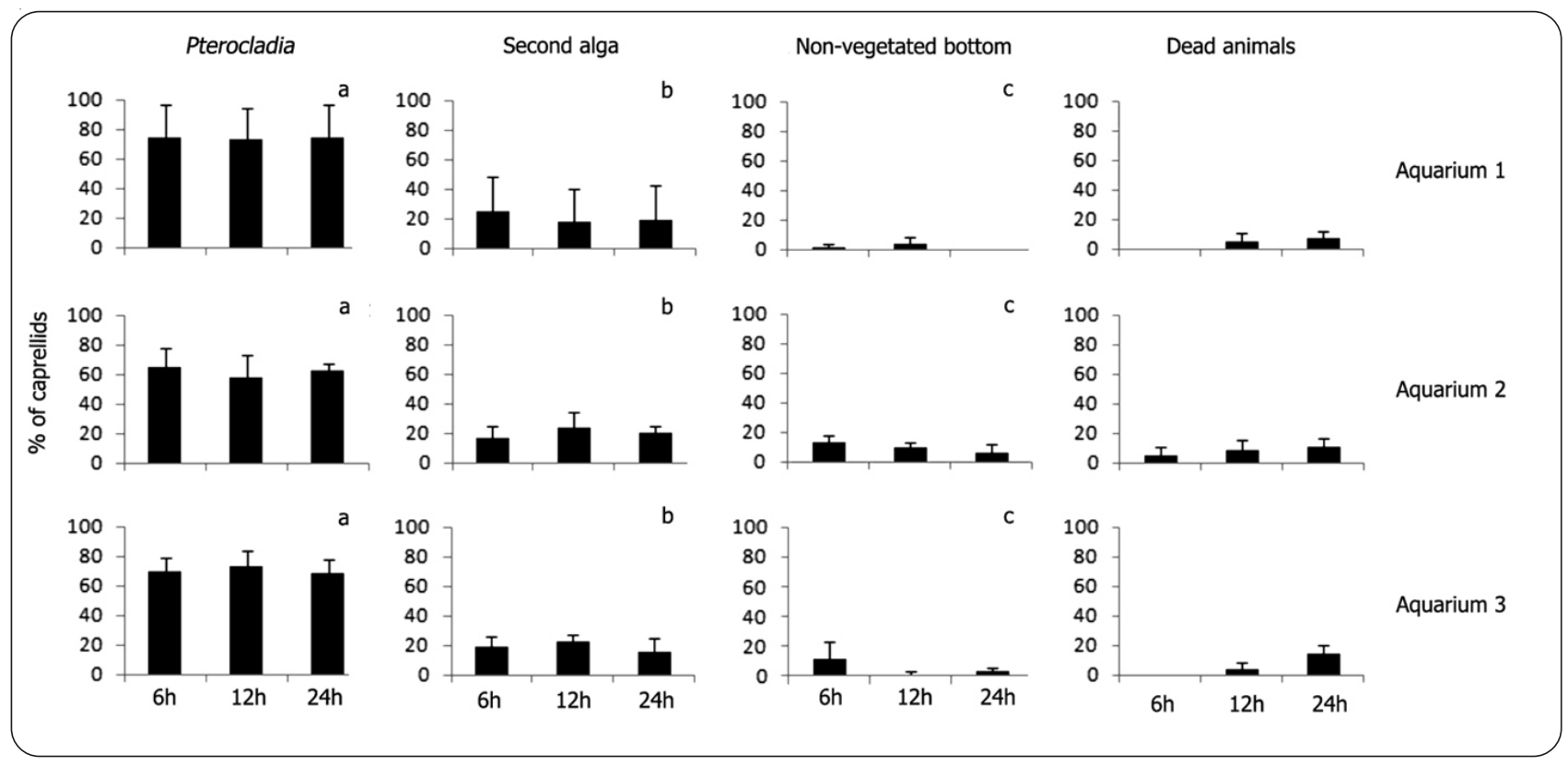

Figure 2. Pterocladia treatment (initial $n=20$ ). Percentage average of caprellids found in the three counts $(6,12$ and $24 \mathrm{~h}$ ) in each algal substrate. Algae combination per aquarium as shown in Table 1. Different letters indicate significant differences (Tukey's post hoc tests, $\mathbf{P}<\mathbf{0 . 0 5}$ ) / Tratamiento de Pterocladia (inicial $n=20$ ). Porcentaje medio de caprélidos en tres observaciones $(6,12$ y $24 \mathrm{~h}$ ) en cada sustrato de algas, según combinaciones de pares de algas por acuario mostrados en Tabla 1. Letras distintas indican diferencias significativas (Tukey post hoc, $\mathrm{P}<0,05$ ) 


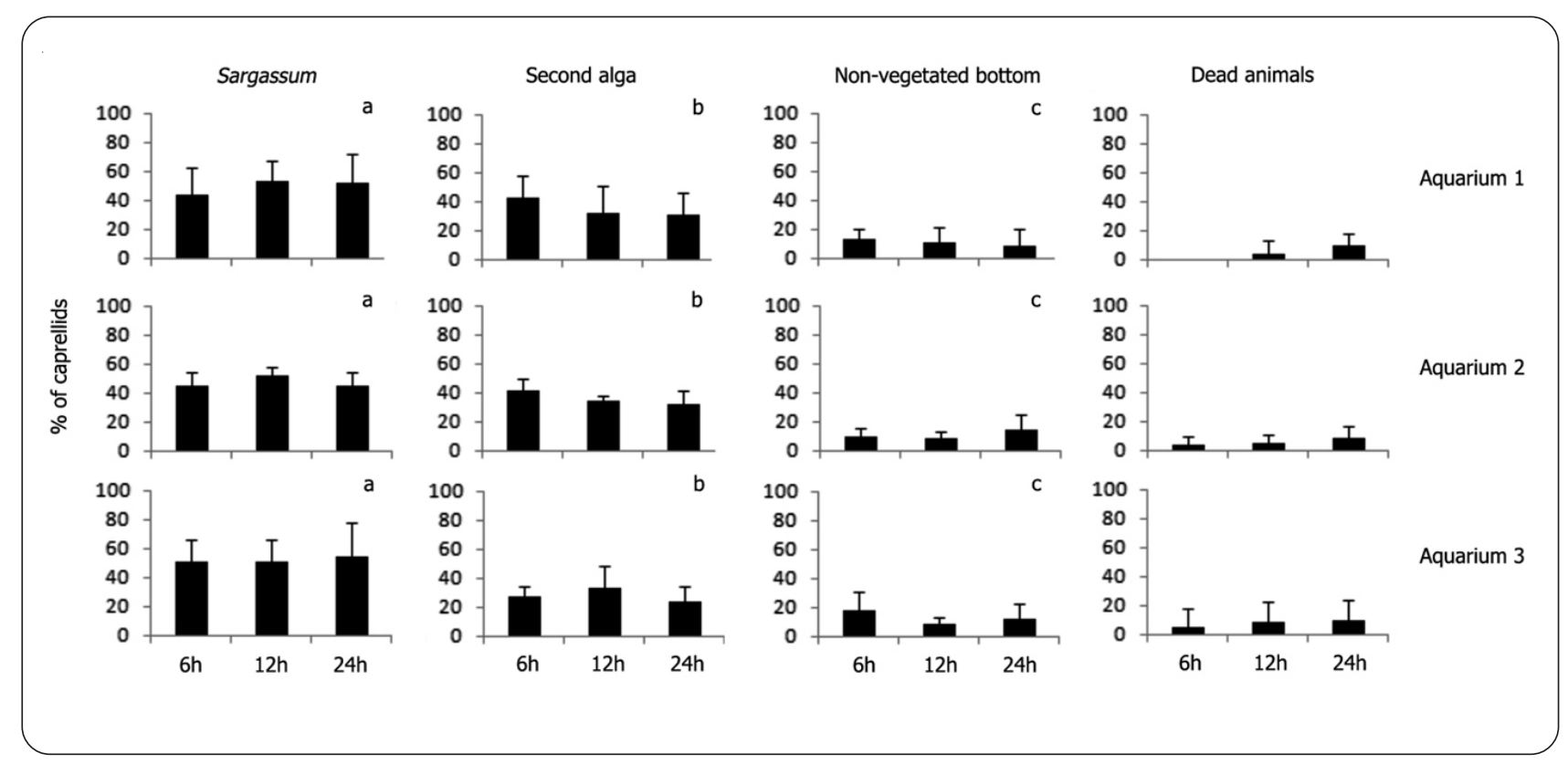

Figure 3. Sargassum treatment (initial $n=15)$. Percentage average of caprellids found in the three counts $(6,12$ and $24 \mathrm{~h})$ in each algal substrate. Algae combination per aquarium as shown in Table 1. Different letters indicate significant differences (Tukey's post hoc tests, $\mathbf{P}$ < 0.05) / Tratamiento de Sargassum ( $\mathrm{n}$ inicial $=15$ ). Porcentaje medio de caprélidos en tres observaciones $(6,12$ y $24 \mathrm{~h}$ ) en cada sustrato de algas, según combinaciones de pares de algas por acuario mostrados en Tabla 1. Letras distintas indican diferencias significativas (Tukey post hoc, $\mathrm{P}<0,05$ )

During the experiments, the migration of caprellids from an algal substrate to another was often observed. It was verified that between $12 \mathrm{~h}$ and $24 \mathrm{~h}$ of observation, the mortality number of the caprellids increased. In the Gracilaria treatment, more caprellids died than in others, with an average of 2.8 animals dying during this experiment, whereas in the Pterocladia treatment, this value fell to 1.2, and in Sargassum, it fell to 0.9.

\section{EXPERIMENTS IN AQUARIA CONTAINING FOUR SPECIES OF}

\section{ALGAL SUBSTRATES}

In the Pterocladia treatment, caprellids showed a preference for Pterocladia, followed by Sargassum and Gracilaria. Caprellids showed a weak preference for Ulva and non-vegetated bottoms (Fig. 4A).

In contrast, in the Sargassum treatment, no significant differences (Fig. 4B) were observed between the number of caprellids that colonized this alga and that of Pterocladia. Caprellids showed a weak preference for the remaining algal substrates and the non-vegetated bottoms (Fig. 4B).

During 24-hour experiments, there was a dynamic variation in the number of caprellids in the algal substrates, likely due to their migrations from one substrate to another. However, the total number of caprellids decreased significantly during this period as a consequence of higher mortality rates. In both treatments, the number of dead caprellids increased drastically after $24 \mathrm{~h}$.

\section{Discussion}

Caprella dilatata was only recorded in about $32 \%$ of a total of 34 analyzed substrates. This restricted occurrence (four of 19 analyzed phytals, four of ten animal colonies and three of five artificial substrates) in some substrates questions the general assumption that this species has a cosmopolitan character for substrate selection due to the presence of grasping spines on pereopods 5-7 and 6segmented pereopod 5 is usually inserted posteriorly on pereonite 5 (Caine 1978).

Although recorded from varied substrates (Jacobucci et al. 2002, Masunari \& Takeuchi 2006) and among 11 analyzed substrates in the present study, individuals of $C$. dilatata were recorded only from finely branched and softly surfaced algae, such as Pterosiphonia and Pterocladia and, in a lower frequency, Gracilaria and Sargassum. However, the rigid surfaced bryozoan Bugula neritina harbored the third most abundant population of 


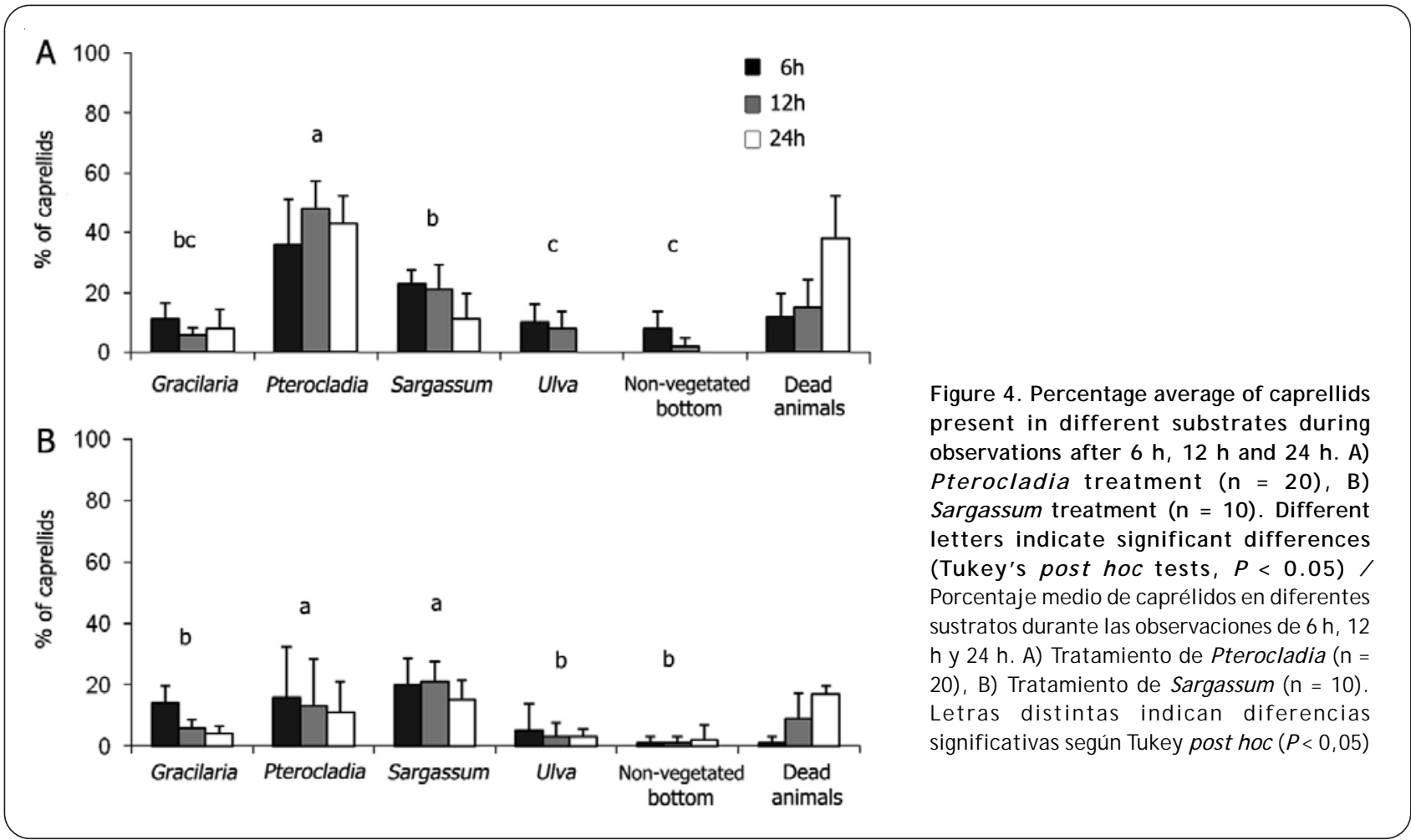

C. dilatata. These caprellids were certainly attracted by a potential food resource in the bryozoan zoocites (Mayer 1882), similar to gorgonians (Scinto et al. 2008). In contrast, the strongly colonized man-made structures can be explained by a dense growth of pioneer algae on the surface of buoys and by a suitable rugosity of ropes for the secure anchorage of these caprellids.

The experiments showed that the alga Ulva seems to be the least attractive alga-substrate for $C$. dilatata, as already reported by Keith (1971) for C. californica and C. equilibra. This is attributed to the wideness and flexibility of its thallii that can hinder the prehension of the caprellids. Consequently, macroalgae with simple thallii tend to shelter less-abundant invertebrates with a lower diversity than those with complex architecture (Gunnill 1982, Gee \& Warwick 1994).

Additionally, the strong preference of $C$. dilatata for its original algal substrate in the present study points out the importance of camouflage for these animals, as they always exhibited body color very similar to that of the substrate. This observation is in accordance to Keith's (1971) experiments with C. californica Stimpson, 1857, and the substrates Bugula neritina (Linnaeus, 1758), Polysiphonia pacifica Hollenberg, and Ulva lobata
(Kützing) Harvey. Despite certain influences from the original substrate, this caprellid chose the bryozoan $B$. neritina in all treatments. The author attributed this result to the similarities in morphology and color between the caprellids and the bryozoan, pointing out that the need for camouflage surpassed that of substrate fidelity.

Although no bryozoan was included in the present experiments, it can be inferred that $C$. dilatata possesses the ability to maintain the color of its exoskeleton over a short period of time according to its needs. After colonizing a specific alga, these caprellids seem to develop a color as close as possible to the present substrate. In this context, the development of techniques involving longterm experiments are highly desirable to ascertain whether color changing is possible if the caprellids are moved to another alga with a different color than the original. In the present study, caprellid death rates increased significantly after $24 \mathrm{~h}$ of experimental handling.

The above hypothesis regarding caprellid color plasticity is based on the observation of Caine (1978), who reported that individuals of $C$. penantis and $C$. equilibra, when associated with bryozoan and gorgonians, exhibited intraspecific morphological variation, including a reduction in the number of setae 
and in the size and number of grasping spines of the pereopods for the first species and a reduction in the length of the ventral spine inserted between gnathopods for the second species. These variations, according to the author, can be decisive in association success with the substrate.

The experiments with four-algal substrates in each aquarium showed that Pterocladia is the favorite substrate of caprellids coming from this phytal; however, surprisingly, those living on Sargassum showed equal preference for these two algae. Certainly, in the presence of Gracilaria and Ulva, the behavior in selecting substrates of the caprellids coming from Sargassum (that are larger and more robust) exhibited alteration. In the experiment with two-algal substrates, these animals showed differing preference to the original substrate (Fig. 3 , aquarium 2), indicating that variables other than the necessity of camouflage are influencing this process.

The morphometry of the axes of algal substrate treated in the present study showed that the average width or diameter of the main axis of Pterocladia $(1.14 \mathrm{~mm})$ was very close to Sargassum's (1.10 mm), which can explain the similarity in the number of caprellids that chose these two-algal substrates. Despite the fact that Gracilaria's width or diameter $(1.49 \mathrm{~mm})$ was not significantly different from the two algae above, it seemed to be inadequate for bearers of minuscule prehensile pereopods because it was weakly colonized by caprellids. This supposition is based on Caine's (1978) observation that caprellid species living on algae and hydroids require substrates highly ramified with small diameters in most branches to allow caprellid pereopods to encircle them in such a way that the propodus palm and grasping spines have broad contact with the branch surface. However, the secondary axes of Gracilaria with a width of $1.08 \mathrm{~mm}$ would be an appropriate alternative for the prehension of the caprellids, but this has not been observed.

In addition to the architecture and color of the algal substrate, biological variables such as exudation should be taken in account. Various species of algae have developed structural, morphological or chemical defenses against herbivores that can significantly reduce the susceptibility to strong damage (Duffy \& Hay 1990, Hay 1996). Defensive characteristics can vary considerably according to algal tissues, and this variation has a strong influence on a herbivore's preference for special parts of the plant (Van Alstyne 1988, Cronin \& Hay 1996).
Moreover, some algae are more palatable for amphipod predators than others, inducing them to form an uneven distribution (Holmlund et al. 1990). Based on this data, and the visible production of gelatinous liquid by Gracilaria after two days from its removal, supports that the highest mortality of caprellids recorded in the aquaria containing Gracilaria might have been a consequence of the production of noxious substances by this algal, as a consequence of stress during its removal from the natural rocky substrate.

The difference in the number of caprellids that selected substrates was low between counting intervals (6,12 and $24 \mathrm{~h}$ ) in most treatments, and significant differences were only recorded in the Gracilaria treatment, reinforcing the idea that this alga exuded harmful substances. The non-vegetated spaces were densely occupied only in the first six hours, and the number of caprellids was reduced gradually within that period of time. This fact allows inference that this period (six hours) is long enough for the selection and colonization of substrates by these animals.

Due to the significant mortality of the caprellids after $24 \mathrm{~h}$ of observation, it is likely that the experiments would have been unsuccessful had they been carried out for longer than $24 \mathrm{~h}$. This low longevity was already reported in a study by Meadows (1964) with amphipods in the genus Corophium in which he determined the experimental period of three hours for each replicate of each treatment. In another study with caprellids, the observation period was $48 \mathrm{~h}$ (Keith 1971).

Despite the cosmopolitan nature of $C$. dilatata for substrate selection, according to morphological characteristics proposed by Caine (1978), the species was only found in $30 \%$ of substrates, and most of them were structurally complex. The strong preference of this species for original alga-substrate in the present study highlights the importance of camouflage by keeping similar coloration to the substrate. Besides the compatibility of substrate characteristics such as architecture and color, factors such as the rate of exudation from the algalsubstrate could be influencing the substrate selection behavior of this caprellid.

\section{ACKNOWLedgMenTs}

We thank the Laboratory for Cnidaria Studies, Laboratory for Ecology and Systematic of Ascidiacea, and Laboratory 
for Benthos, all belonging to the Federal University of Paraná and the Museum of Natural History of Capão da Imbuia for the access of caprellid samples deposited in their collections. This work was funded by the Brazilian Council for Scientific and Technological Development (CNPq) with grant number 131173/2008-1. English revision was performed by Elsevier Language Editing. This is Contribution No. 1823 of Zoology Department, Federal University of Paraná.

\section{LITERATURE CITED}

Aoki M. 1999. Morphological characteristics of young, maternal care behaviour and microhabitat use by caprellid amphipods. Journal of the Marine Biological Association of the United Kingdom 70: 629-638.

Barbosa FC, DLG Faria, LDV Nascimento \& DLS Diniz. 2008. Columbídeos: um estudo de caso sobre populações de espécies e suas relações com o ambiente. Revista Ciências do Ambiente On-Line 4(1): 6-15.

Borges RC \& AFB Araújo. 1998. Seleção de habitat em duas espécies de jararaca (Bothrops moojeni Hoge e B. neuwiedi Wagler) (Serpentes, Viperidae). Revista Brasileira de Biologia 58(4): 591-601.

Caine EA. 1978. Habitat adaptations of North American caprellid Amphipoda (Crustacea). The Biological Bulletin 155: 288-296.

Cronin G \& ME Hay. 1996. Effects of light and nutrient availability on the growth, secondary chemistry, and resistance to herbivory of two brown seaweeds. Oikos 77: 93-106.

Dubiaski-Silva J \& S Masunari. 1995. Ecologia populacional dos Amphipoda (Crustacea) dos fitais de Caiobá, Paraná. Revista Brasileira de Zoologia 12(2): 373-396.

Duffy JE \& ME Hay. 1990. Seaweed adaptation to herbivory. Bioscience 40: 368-375.

Dutra RRC. 1988. A fauna vágil do fital Pterocladia capillacea (Rhodophyta Gelidiaceae) Ilha do Mel, Paraná, Brasil. Revista Brasileira de Biologia 48(3): 589-605.

Fenchel T. 1975. Factors determining the distribution patterns of muds snails (Hydrobiidae). Oecologia 20: 1-17.

Fenchel T \& LH Kofoed. 1976. Evidence for exploitative interspecific competition in mud snails (Hydrobiidae). Oikos 27: 367-376.

Gee JJ \& RM Warwick. 1994. Metazoan community structure in relation to the fractal dimension of marine macroalgae. Marine Ecology Progress Series 103: 141-150.

Guerra-García JM. 2001. Habitat use of the Caprellidea (Crustacea: Amphipoda) from Ceuta, North Africa. Ophelia 55(1): 27-38.
Gunnill FC. 1982. Effects of plant size and distribution on the numbers of invertebrate species and individuals inhabiting the brown alga Pelvetia fastigiata. Marine Biology 69: 263-280.

Gustafsson L. 1987. Interspecific competition lowers fitness in collared flycatchers Ficedula albicollis: an experimental demonstration. Ecology 68: 291-296

Hay ME. 1996. Marine chemical ecology: what is known and what is next? Journal of Experimental Marine Biology and Ecology 200: 103-134.

Holmlund MB, CH Peterson \& ME Hay. 1990. Does algal morphology affect amphipod susceptibility to fish predation? Journal of Experimental Marine Biology and Ecology 139: 65-83.

Jacobucci GB, D Moretti, EM Silva \& FPP Leite. 2002. Caprellid amphipods on Sargassum cymosum (Phaeophyta): depth distribution and population biology. Nauplius 10(1): 27-36.

Keith DE. 1971. Substrate selection in caprellid amphipods of Southern California, with emphasis on Caprella californica Stimpson and Caprella equilibra Say (Amphipoda). Pacific Science 25: 387-394.

Krapp-Schickel T. 1993. Suborden Caprellidea. In: Ruffo (ed). The Amphipoda of the Mediterranean. Mémoires de L'Institute Oceanographique, Monaco 13(3): 773-813.

Leite FPP \& A Turra. 2003. Temporal variation in Sargassum biomass, Hypnea epiphytism and associated fauna. Brazilian Archives of Biology and Technology 46(4): 665671.

Leite FPP, MO Tanaka, DB Sudatti \& RS Gebara. 2007. Diel density variation of amphipods associated with Sargassum beds from two shores of Ubatuba, Southeastern, Brazil. Iheringia, Série Zoologia 97(4): 400-405.

McCain JC. 1968. The Caprellidae (Crustacea: Amphipoda) of the Western North Atlantic. United States, National Museum Bulletin 278: 1-116.

Martin TE. 2001. Abiotic vs. biotic influences of habitat selection on coexisting species: climate change impacts? Ecology 82: 175-188.

Masunari S. 1982. Organismos do fital de Amphiroa beauvoisii. I. Autoecologia. Boletim de Zoologia, Universidade de São Paulo 7: 57-148.

Masunari S \& I Takeuchi. 2006. Redescription of Caprella dilatata Krøyer, 1843 (Caprellidae: Amphipoda: Crustacea) from Brazil, with note on its biogeographical distribution in South America. Zootaxa 1298: 49-60.

Mayer P. 1882. Die Caprelliden des Golfes von Neapel und der angrenzenden Meeres-Abschnitte. Fauna und Flora des Golfes von Neapel 6: 1-201. 
Meadows PA. 1964. Substrate selection by Corophium species: the particle size of substrates. Journal of Animal Ecology 33(3): 387-394.

Morris DW. 2003. Toward an ecological synthesis: a case for habitat selection. Oecologia 136(1): 1-13.

Robinson SK, FR Thompson, TM Donova, DR Whitehead \& J Faaborg. 1995. Regional forest fragmentation and the nesting success of migratory birds. Science 267: 1987-1990.

Rosenberg DK \& KS Mckelvey. 1999. Estimation of habitat selection for central-place foraging animals. The Journal of Wildlife Management 63(3): 1028-1038.

Rosenzweig ML. 1981. A theory of habitat selection. Ecology 62(2): 327-335.

Scinto A, G Bavestrello, M Boyer, M Previati \& C Cerrano. 2008. Gorgonian mortality related to a massive attack by caprellids in the Bunaken Marine Park (North Sulawesi, Indonesia). Journal of the Marine Biological Association of the United Kingdom 88(4): 723-727.

Serejo CS. 1998. Gammaridean and Caprellidean fauna (Crustacea) associated with the sponge Dysidea fragilis Johnston at Arraial do Cabo, Rio de Janeiro, Brazil. Bulletin of Marine Science 63(2): 63-85.
Sinervo B \& D DeNardo. 1996. Costs of reproduction in the wild: path analyses of natural selection and experimental tests of causation. Evolution 50: 1299-1313.

Shima JS \& CW Osenberg. 2003. Cryptic densitydependence: effects of covariation between density and site-quality in reef fish. Ecology 84: 46-52.

Shucksmith R, EJ Cook, DJ Hughes \& MT Burrows. 2009. Competition between the non-native amphipod Caprella mutica and two native species of caprellids Pseudoprotella phasma and Caprella linearis. Journal of the Marine Biological Association of the United Kingdom 89: 11251132.

Takeuchi I \& R Hirano. 1995. Clinging behavior of the epifaunal caprellids (Amphipoda) inhabiting the Sargassum zone on the Pacific coast of Japan, with its evolutionary implications. Journal of Crustacean Biology 15(3): 481-492.

Thiel M, JM Guerra-Garcia \& DA Lancellotti. 2003. The distribution of littoral caprellids (Crustacea: Amphipoda: Caprellidea) along the Pacific coast of continental Chile. Revista Chilena de Historia Natural 76(2): 297-312.

Van Alstyne KL. 1988. Herbivore grazing increases polyphenolic defenses in the intertidal brown alga Fucus distichus. Ecology 69: 655-663.

Received 10 February 2011 and accepted 30 May 2011 